\title{
Management principles and their application as a strategic guideline for sustainable business development
}

\author{
Elena Popova ${ }^{1}$, Vladimir Bazelyuk ${ }^{1}$, Nadezhda Demina ${ }^{1}$, Alexander Demin ${ }^{1}$, and Tatiana \\ Letaeva $^{2}$ \\ ${ }^{1}$ South Ural State University (national research university), Lenin Str., 76, 454080 Chelyabinsk, \\ Russia \\ ${ }^{2}$ Technological Institute, a branch of the National Research Nuclear University MEPhI, \\ Kommunistichesky Ave., 36, 624200 Lesnoy, Russia
}

\begin{abstract}
The fundamental principles of management, as well as the practice of their application in industrial production sphere are described in the article in detail. The author gives an idea of the managerial principles evolution in an enterprise-type organization (both in our country and abroad). Special attention is paid to the managerial culture formation theory and its influence on the entrepreneurial and strategic management combination. The main idea of the presented work is an evolutionary approach to effective management principles classification in relation to business activities carried out within self-organizing micro-level systems. Their developmental gene, as shown in the work, is the management culture, its formation is the subject of this study. The study research area is management science issues and its cognition methods development: developmental factors and managerial principles of an enterprise-type organization.
\end{abstract}

\section{Introduction}

In its framework, we will present a brief history of Russian entrepreneurship. It has been discussed since the end of the first Millennium, using the example of trade activities. The mainstay of this business type was a number of cities of Ancient Russia, with their commercial settlements, where transactions were made and contracts were concluded. There is also a well-known tradition of fair trade for various segments of the population, including boyars and princes.

In the same historical period, treaties between Russia and Byzantium were concluded (911, 944, and 971). They regulated such relations as property rights violation, debt obligations, and inheritance.

Then - in the XV century - the notarial form of transactions was introduced, and a hundred years later - the Customs Charter (in accordance with European law). Finally, an active process of creating various workmen's cooperative associations («artels») and partnerships began, including in cooperation with foreign shareholders. Another milestone in the development of entrepreneurship was the adoption of the Bankruptcy Charter. 
Further: the cooperative movement is expanding, and the role of banks and insurance institutions was increasing. And finally, management appeared, as the management of someone else's property by professional managers. This is what will be discussed further in the framework limited by the principles of management and its application in the field of entrepreneurship.

\section{Materials and methods}

The content of the research is a comprehensive one conducted in a number of universities in the southern Urals. It is based on the modern management paradigm of an enterprise-type organization. In this paper, it is presented as a way to make a qualitative breakthrough in the appointment and development of non-standard creative thinking of employees of an industrial enterprise.

The methodological guidelines of the research are also new ideas for approaches to management activities based on such research methods use as SWOT - COPS analysis, as well as modelling and interviewing specialists on the research topic.

\section{Research results and their generalization}

Managers represent a specific factor of business activity. Thanks to them, capital finds a profitable use. «If the company is operating poorly and unprofitable, its owner can dismiss the management» [3]. This refers to the top, middle, and low management of an enterprisetype organization, which main characteristics are as follows (Figure 1).

A modern incorporated enterprise is characterized by various types of management (Table 1). These principles serve as a coordinating ones, forming and setting in motion such organization's resources to achieve its goals [4].

Table 1 shows the types of «entrepreneurial management», called by us [7]. Attention is drawn to its functional orientation. It is also characterized by a skillful combination of administrative and entrepreneurial methods of an incorporated enterprise managing.

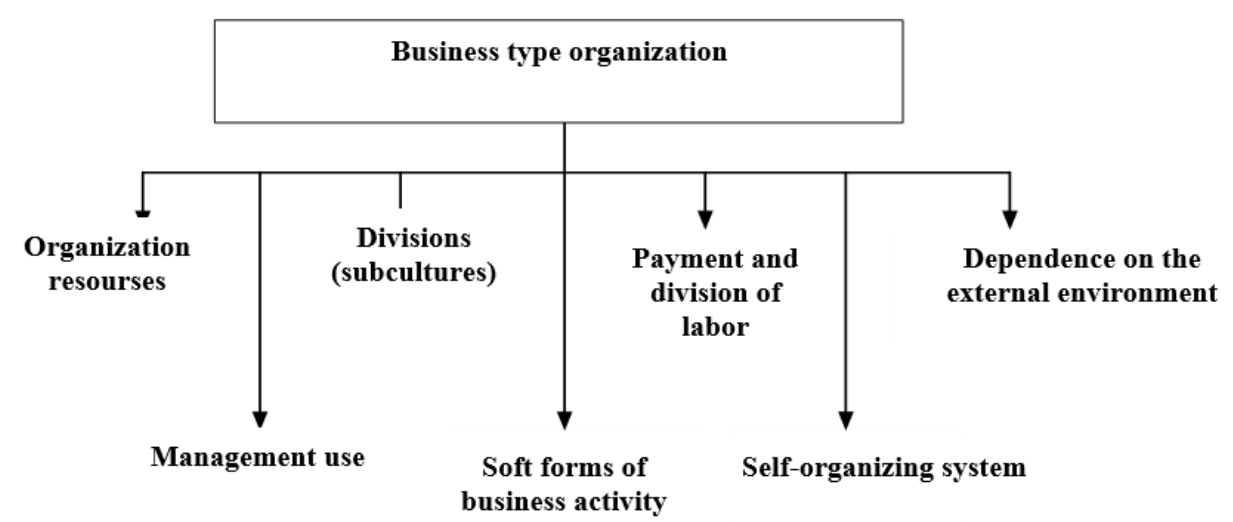

Fig. 1. Basic characteristics of business organization 
Table 1. Organizational management use in business activity sphere

\begin{tabular}{|l|l|}
\hline \multicolumn{1}{|c|}{ Kind } & \multicolumn{1}{c|}{ Substantive aspect } \\
\hline $\begin{array}{l}\text { 1. Production } \\
\text { management }\end{array}$ & $\begin{array}{l}\text { Ongoing production management } \\
\text { The basic production assets as the capital } \\
\text { Optimal production plan }\end{array}$ \\
\hline $\begin{array}{l}\text { 2. Financial } \\
\text { management }\end{array}$ & $\begin{array}{l}\text { Working capital of an enterprise-type organization } \\
\text { Financial stability and solvency } \\
\text { Management of business activities (BA) control and analysis }\end{array}$ \\
\hline $\begin{array}{l}\text { 3. Marketing } \\
\text { management }\end{array}$ & $\begin{array}{l}\text { Product quality management } \\
\text { Basic principles of product sales management } \\
\text { Marketing as an effective means of increasing competitiveness }\end{array}$ \\
\hline $\begin{array}{l}\text { 4. Personnel } \\
\text { management }\end{array}$ & $\begin{array}{l}\text { Labor remuneration: essence, systems, principles } \\
\text { Motives and incentives for economic behavior } \\
\text { Recruitment and placement of personnel, their training and professional } \\
\text { development }\end{array}$ \\
\hline $\begin{array}{l}\text { 5. Logistical } \\
\text { management }\end{array}$ & $\begin{array}{l}\text { Stock control as a system-forming factor in logistics } \\
\text { Providing function of an incorporated enterprise } \\
\text { Design and optimization of logistics concentration and distribution } \\
\text { systems }\end{array}$ \\
\hline $\begin{array}{l}\text { 6. Management of } \\
\text { economic security } \\
\text { of business } \\
\text { activities }\end{array}$ & $\begin{array}{l}\text { Comprehensive security of business activities } \\
\text { Economic risk assessment and classification of risks and threats for } \\
\text { business activities } \\
\text { Economic security and threats of business acquisitions }\end{array}$ \\
\hline $\begin{array}{l}\text { 7. Organizational } \\
\text { management }\end{array}$ & $\begin{array}{l}\text { Organizational management of an incorporated enterprise } \\
\text { Real-time management } \\
\text { Management performance assessment system }\end{array}$ \\
\hline
\end{tabular}

In the organizational theories classification, we have assigned business management to their applied types (Figure 2). In addition to these, as shown here, we should distinguish between fundamental theories (technological and institutional), which are also relevant to the content of our work.

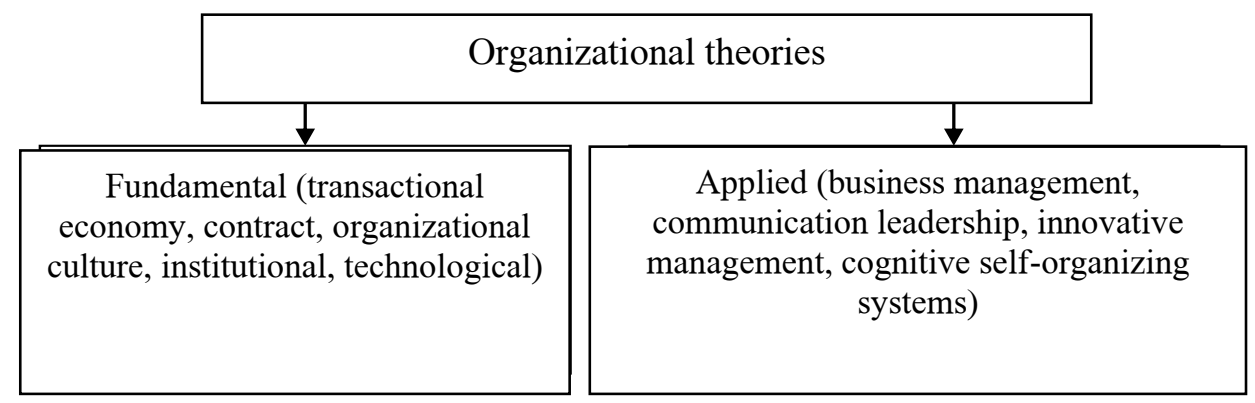

Fig. 2. Simplified classification of business type organizational theories

First of all, strategic management can be spoken about. It examines the issues of formation, analysis, implementation and evaluation of strategic decisions. A special role is given to organizational cultural development.

Let's answer the question: why do we need this type of management? In the most generalized form, the answer to this question is related to the need to reduce the level of uncertainty in business activities by developing an innovative development strategy and related organizational culture. 
The latter, in turn, is organically connected with ensuring the competitive potential of an enterprise-type organization (incorporated enterprise, corporation). And here we will pay attention to the management principle, which sounds like this: the principle of a coordination strategy of early activity.

Coordination (as a figurative representation of the cognition and synergy of the business activity agency center) is a generalizing function of the organization's management system. It goes about a coherent policy for achieving goals, taking into account the need for resources and organizational culture. We can also agree that this approach to business activities strategic development is an intellectual part of management that can be SWOT and COPS - analysis, planning and performance evaluation.

Especially important is the managers', coordinating working activity and setting resources in motion, striving to achieve the goal, and forming the organizational culture of the enterprise. At the same time, its employees, their way of thinking and actions act as culture-bearers. This can be seen from the diagram shown in Figure 3.

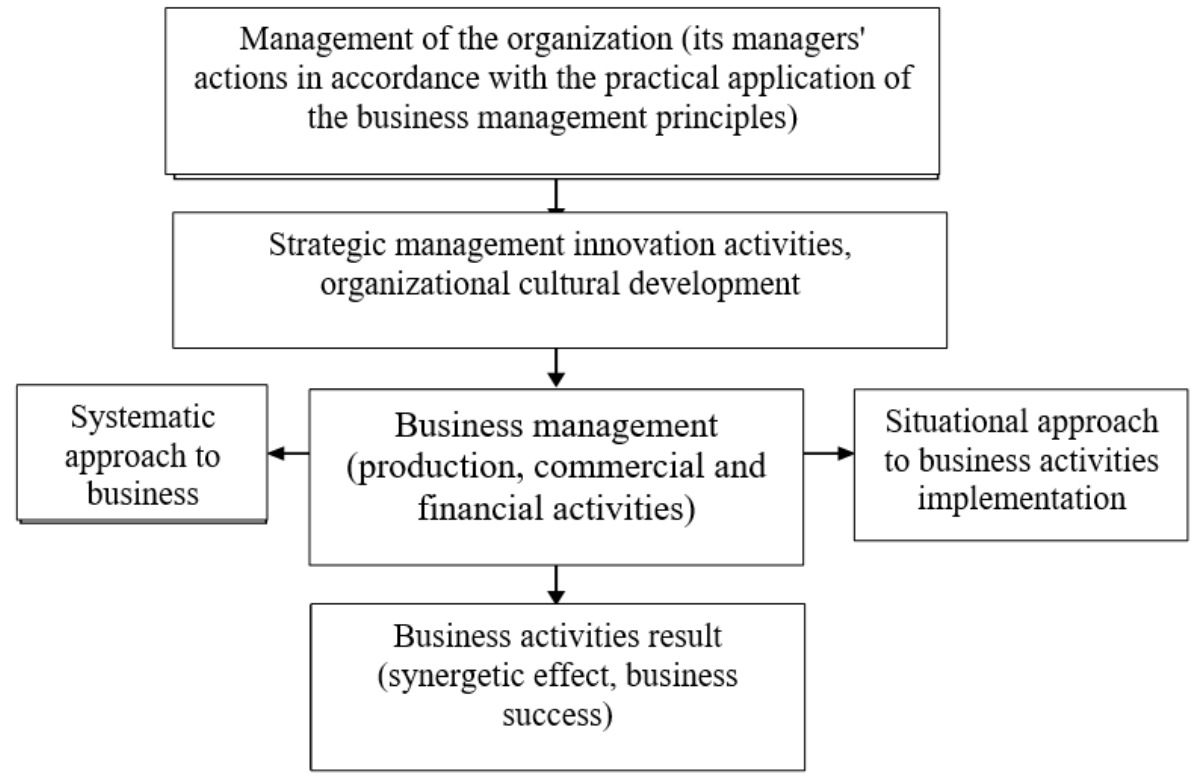

Fig. 3. Cause-and-effect relationships in business type organizations' management system

The principle of management is the fundamental principles of effective business management. We also agree that these are established, ingrained and widespread rules that apply within the framework of business-type management. Let us add that the principles can also be the subject of scientific research, in which they are clarified and even rediscovered.

As an example, we can mention such principles of personnel management as maintaining employees' sense of self-respect, active listening, and others.

In our research, devoted to the business management principles practical application focus is placed on other principles as well. Namely: taking into account emergence, external addition, feedback, and making management decisions based on alternative choices. Management is understood as creativity based on these principles. We also include leadership (personal and collective) related to the agency center of an incorporated enterprise. 
In this case, this principle can be specified (in business terms) as follows: think globally, act locally. The latter concerns «business management», and the first - strategic one, presented by us in the form of the following components (Table 2).

Table 2. Structural presentation of strategic management

\begin{tabular}{|c|l|}
\hline Kind of management & \multicolumn{1}{c|}{ Substantive aspect } \\
\hline \multicolumn{1}{|c|}{ Innovative } & $\begin{array}{l}\text { Kinds and functions of innovation management } \\
\text { Classification of innovations and innovation processes } \\
\text { Innovation management as a system }\end{array}$ \\
& $\begin{array}{l}\text { Innovative manager in the coordinates of business success } \\
\text { Managing subsystem of innovation management } \\
\text { Assessment of the cultural factor role in the implementation of } \\
\text { the innovation strategy }\end{array}$ \\
\hline Cultural development & $\begin{array}{l}\text { Organizational cultural development } \\
\text { BC (ППБK)-vision as a tool for strategic management of an }\end{array}$ \\
& enterprise-type organization \\
& Four main management rings (a retrospective look at their \\
& formation) \\
& Culture-building management as the basis of organizational \\
& culture-building of business activity \\
& Personnel selection in the process of organizational cultural \\
development & Generalized algorithm of works on organizational cultural \\
& development in the business system \\
\hline
\end{tabular}

Culture-building management should be ahead of innovation one (as part of the organization's strategic activities to ensure competitive potential). Otherwise, there will be resistance from some of its members to introduce innovations, since this is often accompanied by some employees' dismissal or their relocation and professional development (retraining). In a more specific form, you can read about this in the work of one of the authors of this article [9].

As a certain generalization of the research results, we present Table 3, entitled «Organization management principles». First, these are the principles of creating a good organization by A. Fayol, whose work was published in our country 80 years ago [11]. Secondly, these are the principles of corporate management published by A. D. Weinberg 20 years ago [1]. Third, it is their modern sound (according to a survey of some top managers from South Ural business organizations).

The first group of principles focuses primarily on the rationality of relations between the manager and his subordinates, while the second group focuses more on the openness of the organization, focused on business success. It is important, according to the author of their publication, "the desire that all members of the organization work with the greatest impact».

Nowadays (in Russian business), some of the principles from the first two groups are of particular importance. But they also include: social responsibility [8], the desire for leadership in organizational culture [10] and (as already noted) a coordination strategy for early activity. 
Table 3. Organization management principles

\begin{tabular}{|c|c|c|c|}
\hline Principle & 80 years ago & 20 years ago & Nowadays \\
\hline $\begin{array}{l}\text { 1.Unity of management } \\
\text { 2. The transfer of authority } \\
\text { 3. Unity of subordination } \\
\text { 4. Matching the level of responsibility and } \\
\text { subordination } \\
\text { 5. Subordinates' number limiting } \\
\text { 6. Communication system certainty } \\
\text { 7. Definiteness of expressed tasks } \\
\text { 8. Selectivity of information } \\
\text { 9. Execution obligation and control } \\
\text { 10. Business planning } \\
\text { 11. Management bodies availability } \\
\text { 12. Organizational structure flexibility } \\
\text { 13. Responsive to external and internal } \\
\text { changes } \\
\text { 14. Optimal distribution of forces and } \\
\text { resources } \\
\text { 15. The desire to ensure that all members } \\
\text { of the organization work with the greatest } \\
\text { impact } \\
\text { 16. Adjustment of current work in order to } \\
\text { achieve business success } \\
\text { 17. Development and adoption of the most } \\
\text { effective solutions } \\
\text { 18. Social responsibility } \\
\text { 19. Striving for leadership in } \\
\text { organizational culture development } \\
\text { 20. Early activities coordinative strategy }\end{array}$ & $\begin{array}{l}+ \\
+ \\
+ \\
+ \\
+ \\
+ \\
+ \\
+ \\
+ \\
+ \\
+ \\
+\end{array}$ & $\begin{array}{l}+ \\
+ \\
+ \\
+\end{array}$ & $\begin{array}{l}+ \\
+ \\
+ \\
+ \\
+\end{array}$ \\
\hline
\end{tabular}

According to our survey, in which 42 respondents took part, other principles were mentioned. But we limited ourselves to the nine listed in Table 3, which are the original leaders from the entire list of principals declared in the survey process. Other surveys conducted with our participation were also taken into account $[2,6]$.

\section{Conclusions}

As a conclusion, we will name the principles of management, which we distinguish among many well - known ones: single authority, motivation, leadership, scientific character, responsibility, proper selection and placement of personnel, efficiency and social responsibility. These are also the principles that we propose to use in practice, namely: social responsibility, the desire for leadership in organizational culture and the principle of coordination strategy of early activity, which is directly related to strategic management. Data from the survey of leading top managers from the southern Urals indicate that their practical application makes it possible to ensure both the efficiency of business activities and competitiveness in the industrial goods market (both regional and departmental).

A number of approaches to assessing industrial organizations' management effectiveness are known, namely: the optimality of decisions made, the cost-effectiveness of the change management process, the impact efficiency over the managed object, and the information transmission and processing reliability. However, a more common approach is based on the correspondence of management activities (of course, if these principles are really such from the point of view of their approximation to reality). 


\section{References}

1. A.D.Weinberg, New businessmen of Russia. Reforms of managers' education (1996)

2. Management and management features of the social sphere in the national economy, 96 (2008)

3. A. N. Popov, G. M. Dement'iev, Management as a cognitariat and the basis for the national wealth formation, 64 (2008)

4. V. A. Pirozhkov, Modern organization's management, 212 (1998)

5. A. N. Popov, G. A. Yarin, Institutional theory of the firm: a managerial approach to the study of the national wealth formation processes, 499 (2012)

6. A. N. Popov, G. N. Pryakhin, Theoretical foundations of cultural development management, 26 (2008)

7. A. N. Popov, S. G. Serikov, Business management: nature, modeling, performance evaluation, 164 (2006)

8. Principles of organizational -economic strategic development (OЭCP) corporate governance, 624 (2000), www.rid.ru

9. G. N. Pryakhin, Economic grounding for organizations' management culture development, 236 (2005)

10. G. N. Pryakhin, I. Yu. Sazonov, A. A. Popova, The leadership role in ensuring business success, 34 (2004)

11. A. V. Fayol, The doctrine of management. Trans. from English, 70 (1924)

12. V. Hoyer, How to do business in Europe. Trans. from English, 252 (1990)

13. V. V. Bazelyuk, E. V. Romanov, A. V. Romanova, Theory and practice of physical culture, Moscow: Theory and practice of physical culture and sport, 1, 29 (2017)

14. V. V. Bazelyuk, E. A. Popova, T. V. Letaeva, A. A. Demin, Theory and practice of physical culture. - Moscow: Theory and practice of physical culture and sport, 8, 99 (2019)

15. T. V. Letaeva, E. A. Popova, A. V. Romanova, D. V. Fedulov, Theory and practice of physical culture, Moscow: Theory and practice of physical culture and sport, 1, 43 (2017) 